DOI: $10.2478 / \mathrm{v} 10047-011-0010-0$

PHYSICAL AND TECHNICAL PROBLEMS OF ENERGETICS

\title{
OPTIMIZATION OF POWER SYSTEM DEVELOPMENT USING ACCELERATION FACTOR FOR POWER FLOW CALCULATION
}

\author{
A. Obusev, I. Oleinikova, Z. Krishans \\ Laboratory for Power System Mathematical Modelling, \\ Institute of Physical Energetics, Latvian Academy of Sciences, \\ Aizkraukles iela 21, Riga, LV-1006, LATVIA
}

The dynamic optimization process is analyzed from the viewpoint of simplifying the power flow calculations. The aim of the work was to reduce the calculation time using all admissible algorithms. Although the conventional iteration methods are simple and fast enough, the use of the so-called relaxation principle leads to increased calculation time. The paper exemplifies the power flow calculation based on the iteration method using acceleration factor. Proposals concerning the modelling of a power system are put forward in the aspect of its future development. ration factor.

Key words: power system, modelling, power flow, iteration method, accele-

\section{INTRODUCTION}

In view of the EU initiative - to further integrate the Baltic States' markets into the EU energy sector (more specifically, the Baltic Energy Market Interconnection Plan (BEMIP)), it should be recognized that it offers an opportunity to ensure energy independence of the Baltic States. The BEMIP includes three directions - the creation of interconnections (mainly covering natural gas and power systems), the wind generation, and the $\mathrm{CO}_{2}$ accumulation scheme [1-3].

The article is focused on the power network modelling and development in Europe. In the next five years significant increase could be expected in the integration of Baltic electricity markets and in the regional market liquidity. The most promising projects of future interconnections concern two cross-border links with Sweden and Finland. One of them is Estlink II, with 650MW power (the cost about 100 million EUR, to be completed by 2014); and the Lithuania - Sweden interconnection, with $700 \mathrm{MW}$ power $(\sim 175$ million EUR from the EU funds, planned completion in 2016). These projects are very important not only for integration of the Baltic power transmission system (along with Scandinavian TS) into the European grid, but also in view of the grid infrastructure to be created for development of the Kurzeme region as well as for intended connection of a large number of potential wind power plants and the planned power plant in Liepaja, with the installed capacity of $400 \mathrm{MW}$. In addition, the „Kurzeme ring” is to increase the Baltic transmission network (TN) capacity in the case of large power import/export using the Lithuanian-Swedish dc cable. For this purpose, the Latvian transmission network is to be supplemented by new $330 \mathrm{kV}$ lines parallel to the 
existing ones, which shows the actuality of research into this problem. This means that it is very topical to create a power system's model in order to visualize the schemes of power plants and substations with due regard for security issues, and to choose the proper automation equipment. To perform the analysis of a whole electrical network a great body of calculations is needed. Therefore, these should be divided into parts, e.g.: 1) development and adaptation of the model; 2) arrangement of power plants and substations, selection and calculation of relay protection and automation systems; 3) technically-economic analysis.

The consideration proposed in this paper concerns the first part of those mentioned above; it would provide solution of the active power flow problem for a transmission network as the whole. The results are intended for the use in the next version of Latvian dynamic model (LDM) program development.

\section{THE ITERATION METHOD}

In the mathematical modelling, the calculation of active power flows in a network plays the central role; its results are used in search for the relevant criteria. In the framework of the task of electric power system dynamic optimization, the power flow calculation should be performed fast and with sufficient accuracy. To do this, special methods should be used.

The calculations were done applying a simplified model of power flows. The voltage moduli for all nodes of transmission network are assumed to be approximately equal and the active resistance - much smaller than the inductive resistance [4]. Then the active flow in link $i j$ will be:

$$
P_{i j}=Y_{i j} \cdot\left(\delta_{i}-\delta_{j}\right),
$$

where $Y_{i j} \quad$ is the link's $i j$ admittance coefficient,

$\delta_{i}, \delta_{j} \quad$ are voltage losses from the feeding centre to the node.

In turn, the admittance coefficient is calculated by the formula:

$$
Y_{i j}=\frac{U_{i j}^{2}}{X_{i j}},
$$

where $U_{i j} \quad$ is the link's $i j$ voltage;

$X_{i j} \quad$ is the link's $i j$ reactance.

The Kirchhoff first rule for node $n$ can be expressed in the form:

$$
\sum_{i j \in V_{n}} a_{i j} \cdot P_{i j}+P_{n}=0
$$

Here $V_{n} \quad$ is the whole set of incident links for node $n$;

$a_{i j}=1$ if $n$ is the first node of link $i j$, otherwise $a_{i j}=-1$;

$P_{n} \quad$ is the load in node $n$. 
The Kirchhoff second rule for circuit $c$ may be expressed as

$$
\sum_{i j \in C} \Delta U_{i j}=0 \text {. }
$$

Observing expressions (1-4), the set of linear equations for calculation of node $i$ potential $\delta_{i}$ [5] can be written in the following way:

$$
\begin{aligned}
& -Y_{11} \delta_{1}+Y_{12} \delta_{2}+\ldots+Y_{1 i} \delta_{i}+\ldots+Y_{1 j} \delta_{j}+\ldots+Y_{1 m} \delta_{m}=P_{1} \\
& Y_{21} \delta_{1}-Y_{22} \delta_{2}+\ldots+Y_{2 i} \delta_{i}+\ldots+Y_{2 j} \delta_{j}+\ldots+Y_{2 m} \delta_{m}=P_{2} \\
& Y_{i 1} \delta_{1}+Y_{i 2} \delta_{2}+\ldots-Y_{i i} \delta_{i}+\ldots+Y_{i j} \delta_{j}+\ldots+Y_{i m} \delta_{m}=P_{i}, \\
& Y_{m 1} \delta_{1}+Y_{m 2} \delta_{2}+\ldots+Y_{m i} \delta_{i}+\ldots+Y_{m j} \delta_{j}+\ldots-Y_{m m} \delta_{m}=P_{m}
\end{aligned}
$$

where $Y_{i i}$ is the node's $i$ self-conductivity coefficient.

In the matrix form we can rewrite (5) as

$$
\mathbf{Y} \boldsymbol{\delta}=\mathbf{P} .
$$

This model (called the direct current model) is used in the LDM. The dc model allows the calculation time to be reduced by an order of magnitude as compared with the alternating current model (described by nonlinear equations with complex values). The accuracy of the former model is sufficient for the development tasks.

The iteration techniques applied in the dc model are simple and fast enough, they are suitable for feasibility analysis and synthesis of optimal tasks in a dynamic statement. The most appropriate are the iterations methods that use the principle of relaxation. The system of potential nodes (matrix (6)) is solved using the expression:

$$
\mathbf{R}=\mathbf{P}-\mathbf{Y} \boldsymbol{\delta},
$$

where $\mathbf{R}$ is the unbalance power vector.

Substituting the $\delta$ values satisfying the system solution into (7), we obtain $R=0$. If some $\delta$ values substituted into (7) do not satisfy the system solution, $R \neq 0$.

Solution of system (6) based on the relaxation principle consists in approximate determination of the node potential, so that for $i=1, \ldots, q$ the following equation is to be solved:

$$
\left|R_{i}\right| \leq \varepsilon_{i}
$$

where $\varepsilon_{i}$ is the allowable power unbalance at node $i$.

In this way we define solutions at which Kirchoff's first rule is observed with accuracy $\varepsilon_{i}$. The algorithm for node potential calculation is shown schematically in Fig. 1 [6]. 


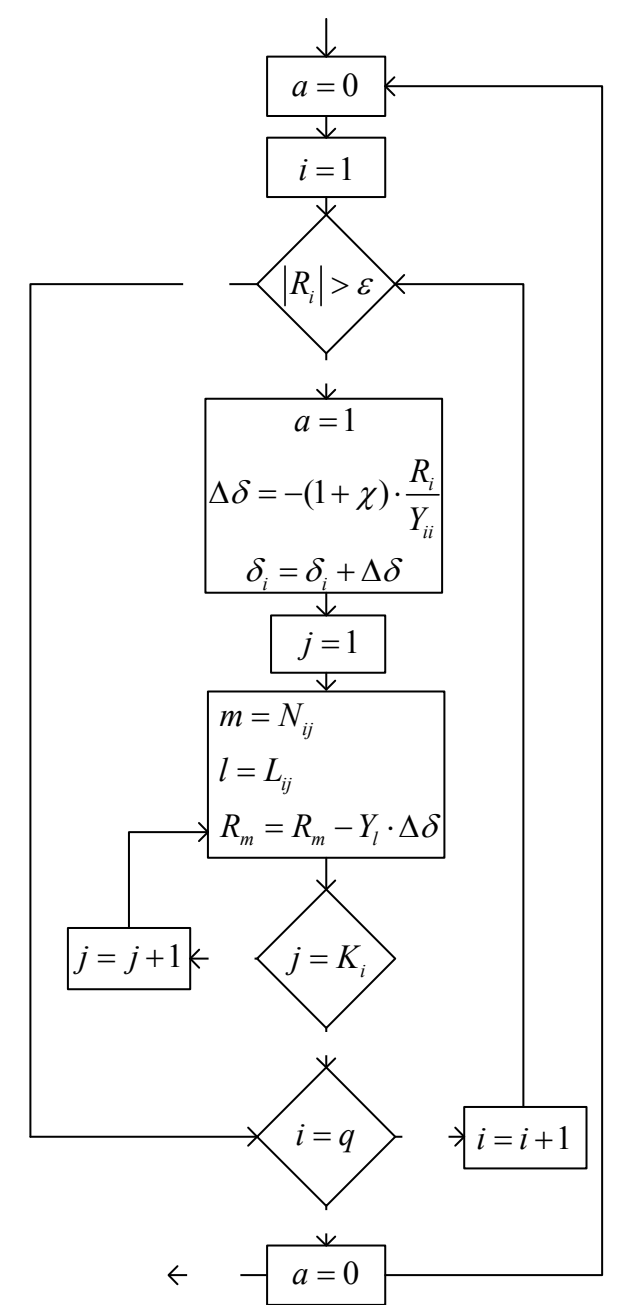

Fig. 1. The algorithm for the node potential calculation.

In the figure: $\chi$ is the acceleration factor,

$N_{i}$ is the array of node numbers $N_{i j}$ directly related to the $i$-th node,

$L_{i} \quad$ is the array of numbers $L_{i j}$ of link outgoing from the $i$-th node,

$K_{i}$ is the number of links outgoing from the $i$-th node.

\section{ACCELERATION FACTOR ANALYSIS USING THE ITERATION METHOD}

The main feature of the active power calculations used in an optimal development task is the manner of doing them. A usual iteration process can be speeded up if we choose the $\chi$ value within the interval from 0 to 1 . At $\chi=0$, in the nodes a monotone convergence of the unbalance power to an acceptable level $\varepsilon$ takes place. In turn, at $\chi>0$ natural fluctuations of the convergence process occur, which leads to a rapid node unbalance decrease in the next iterations and, therefore, to acceleration of the convergence in an iteration process [6]. 


\section{THE OPTIMAL ACCELERATION FACTOR}

To calculate the optimal acceleration factor, the MATLAB software was employed. The calculation was done for a simple system with three nodes, changing the admittance matrix structure. Figure 2 shows a scheme for calculation including structural changes.

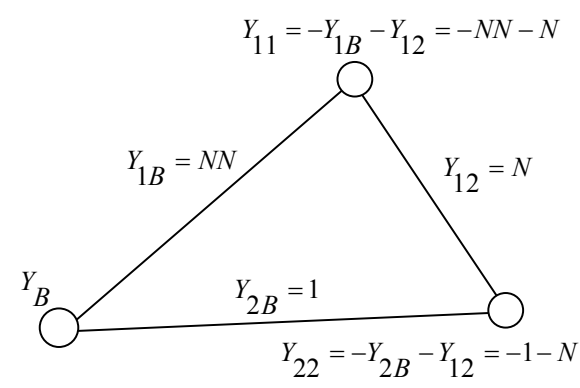

Fig. 2. Scheme of calculations using the method of structural changes.

The $Y$ values can be written in the matrix form:

$$
Y=\left|\begin{array}{cc}
-N N-N & N \\
N & -1-N
\end{array}\right|
$$

where $N N, N$ is the line admittances.

Assuming the structure of initial admittance matrix (9) to be $N N=1$ and changing $N$ in the range from 0 to 50 , we obtain the number of iterations in dependence on the structural changes shown in Fig. 3.

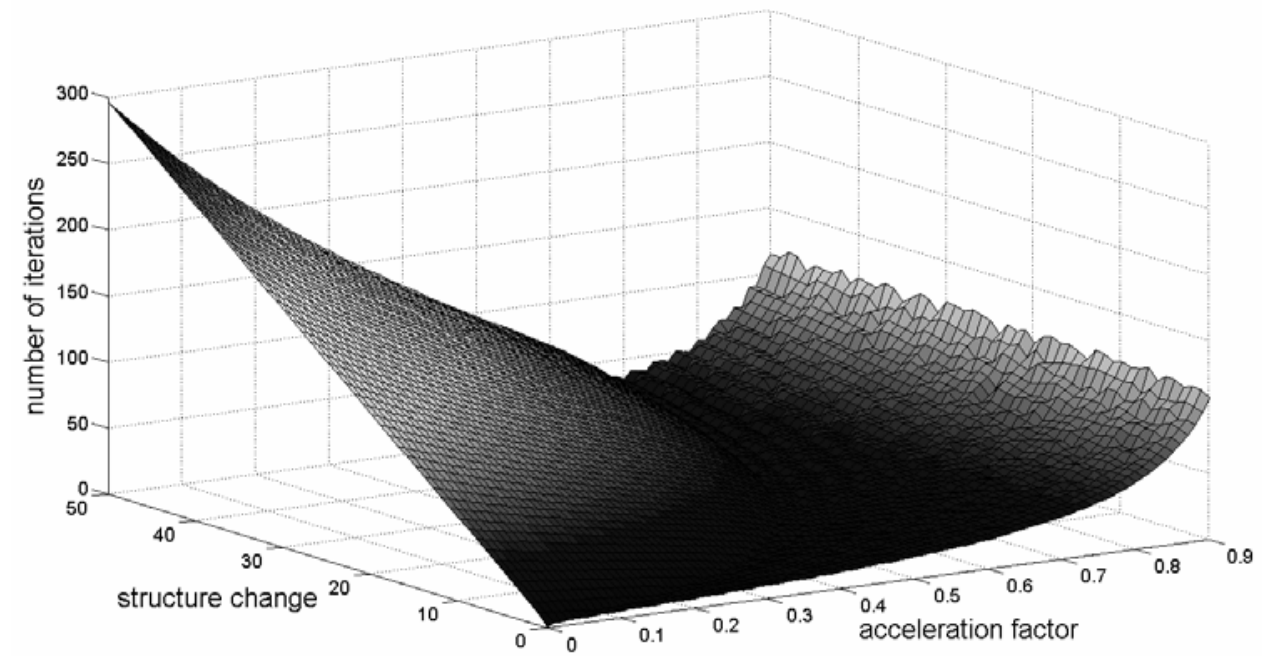

Fig. 3. Changes in the number of iterations at $\mathrm{NN}=1$.

From the calculations it can be deduced that changes in the matrix structure affect the optimal acceleration factor $\chi_{\text {opt }}$ (Fig. 4). 


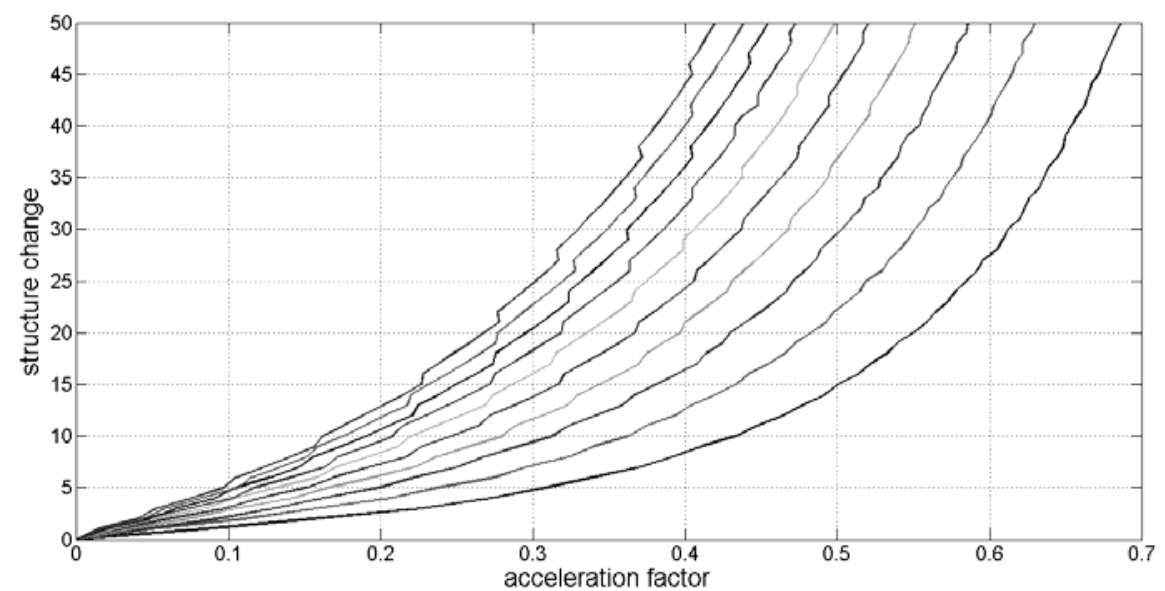

Fig. 4. Variations of acceleration factor at different matrix structures $(N N=1: 10)$.

Using the MATLAB software mathematical devices, the changes in the matrix condition number $K(Y)$ were calculated at different matrix structures depending on the optimal acceleration factor $\chi_{\text {opt }}$ (Fig. 5).

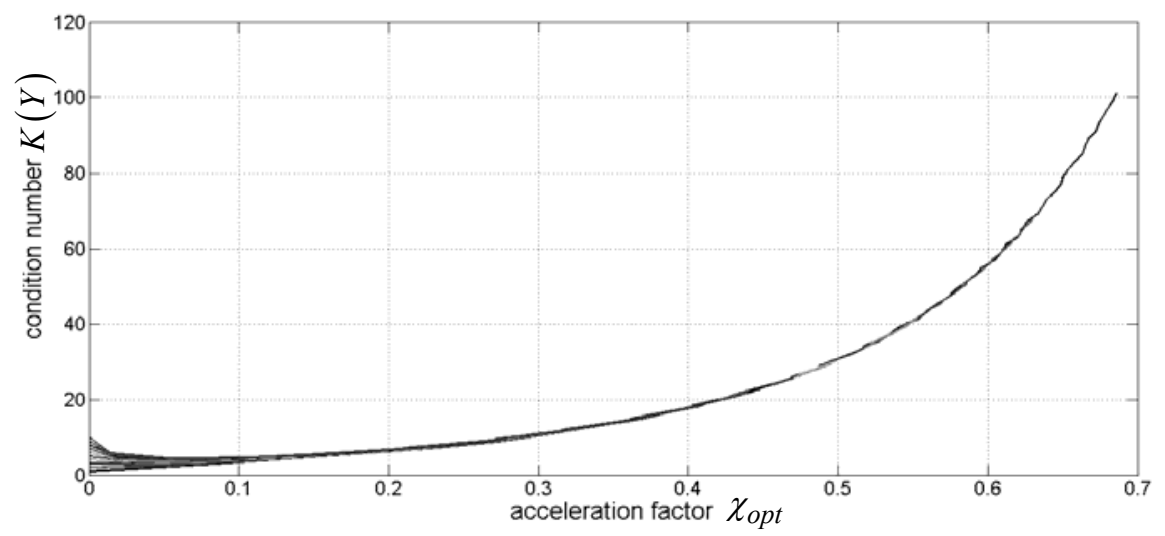

Fig. 5. Matrix condition number vs. acceleration factor.

As a result, correlation between $K(Y)$ and $\chi_{o p t}$ is obtained. The relationships between the values remain the same at different admittance matrix structures.

For further analysis, the curve validating the structure with $N N=1$ was taken into account.

By approximation of the characteristics shown in Fig. 5 the empirical relationship $\chi_{\text {opt }}=f(K(Y))$ consisting of four parts (see Fig. 6) was obtained:

$$
\chi_{\text {opt }}=\left\{\begin{array}{l}
K(Y) \leq 1.5 \quad \Rightarrow 0 \\
1.5<K(Y) \leq 15 \Rightarrow 0.2471 \cdot(K(Y))^{0.363}-0.2869 \\
15<K(Y) \leq 260 \Rightarrow-1.665 \cdot(K(Y))^{-0.2576}+1.191 \\
K(Y)>260 \Rightarrow-2.433 \cdot(K(Y))^{-0.4322}+1.009
\end{array}\right\},
$$

where $K(Y)$ is the matrix condition number. 


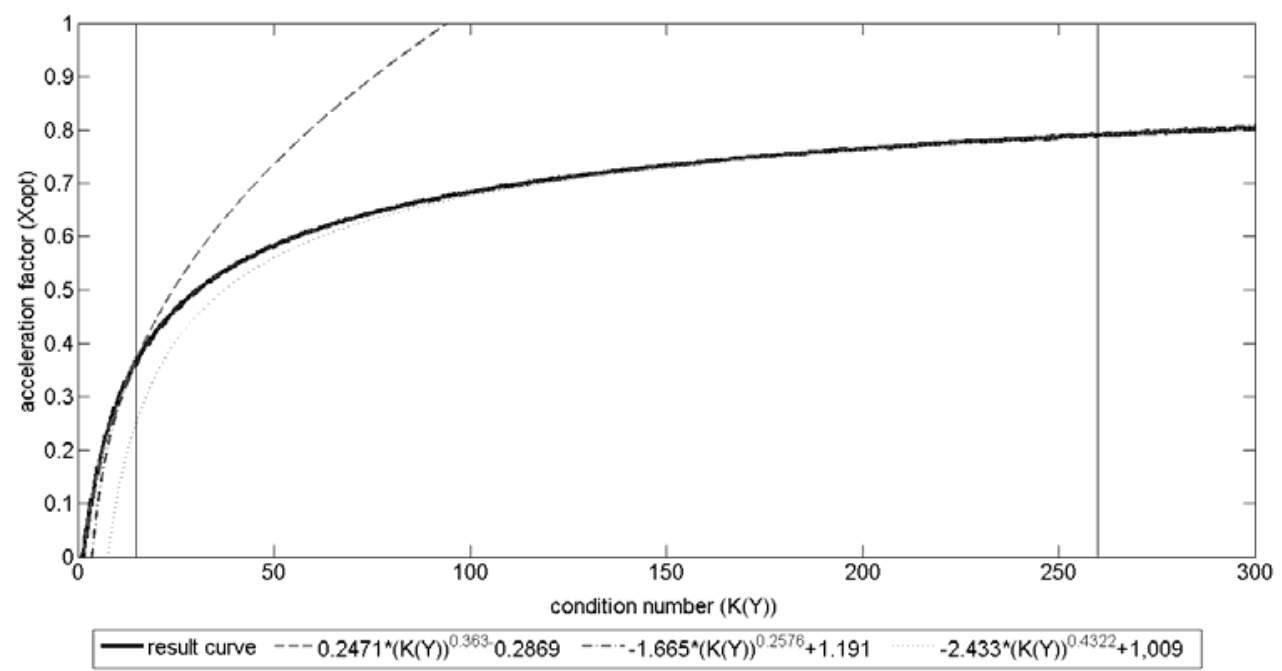

Fig. 6. Acceleration factor $v$ s. matrix condition number.

Before starting the iteration process the admittance matrix condition number had been found; then, using empirical equations (10) the $\chi_{\text {opt }}$ value was calculated with $K(Y)$ being in an appropriate range. After that the iteration process (Fig. 1) was started using the found value of acceleration factor.

\section{TEST RESULTS}

The calculations were done in the MATLAB environment using $1.90 \mathrm{GHz}$ AMD Turion 64 x2 PC with 2048 MB of RAM. Three systems were tested: the 6-node system (Fig. 7), the IEEE 14- and 30- [7] bus systems.

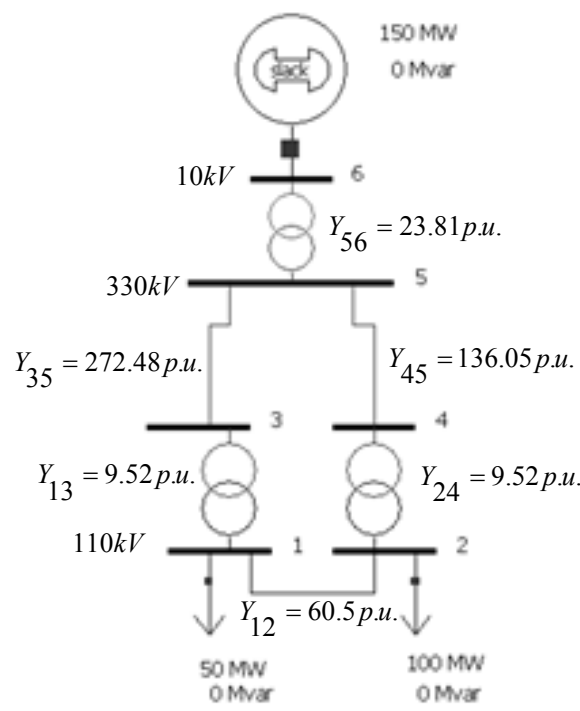

Fig. 7. Scheme of the 6-bus test system.

At testing the 6-bus system (Fig. 7) the following data were obtained: the admittance matrix condition number $K(Y)=181.9$, and the calculated acceleration 
factor $\chi_{\text {opt }}=0.76$. The iteration process time without acceleration was $28.8 \cdot 10^{-3} \mathrm{~s}$ $(\chi=0)$, with the calculated acceleration of $5.33 \cdot 10^{-3} \mathrm{~s}(\chi=0.755)$ (in the calculations the time needed for defining the condition number was taken), and the process time with optimal acceleration was $3.52 \cdot 10^{-3} \mathrm{~s}(\chi=0.67)$. The test results are shown in Fig. 8.

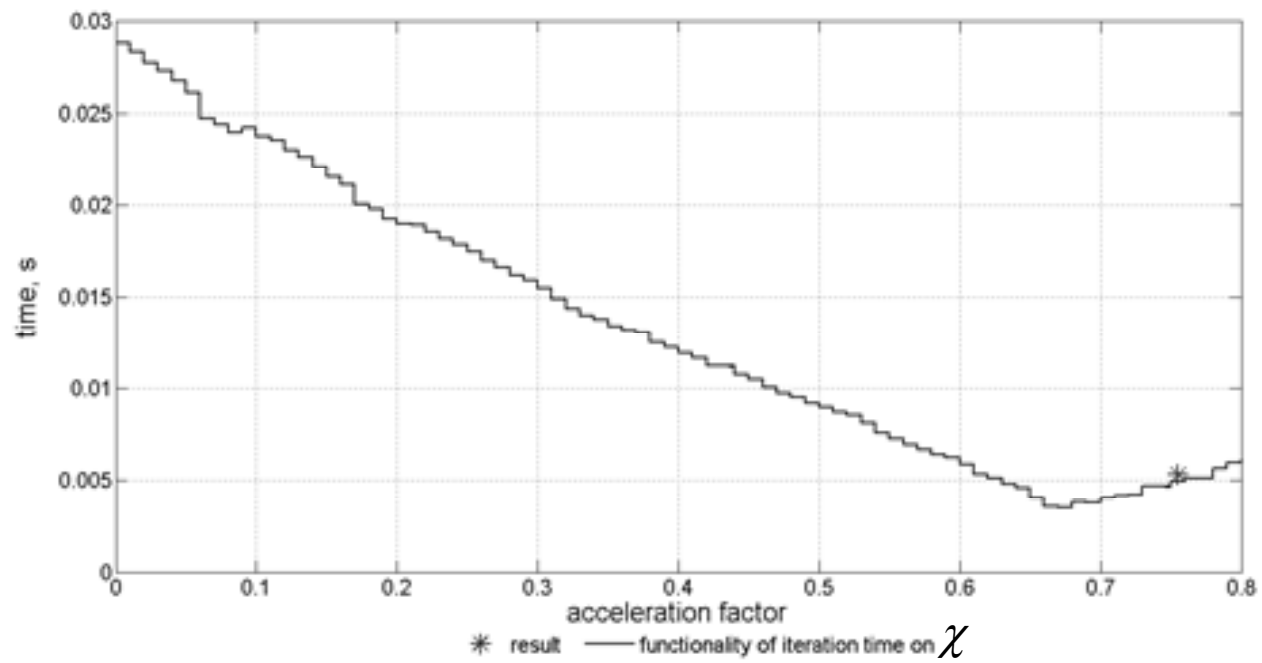

Fig. 8. Test results for the 6-bus system.

For the IEEE 14-bus system the following results were obtained: the admittance matrix condition number $K(Y)=102.68$; the calculated acceleration factor $\chi_{\text {opt }}=0.686$; the iteration process time without acceleration $29.86 \cdot 10^{-3} \mathrm{~s}(\chi=0)$, with calculated acceleration $7.9 \cdot 10^{-3} \mathrm{~s}(\chi=0.686)$ taking into account the time needed to define the condition number; the process time with optimal acceleration $5.1 \cdot 10^{-3} \mathrm{~s}(\chi=0.58)$. The test results are shown in Fig. 9 .

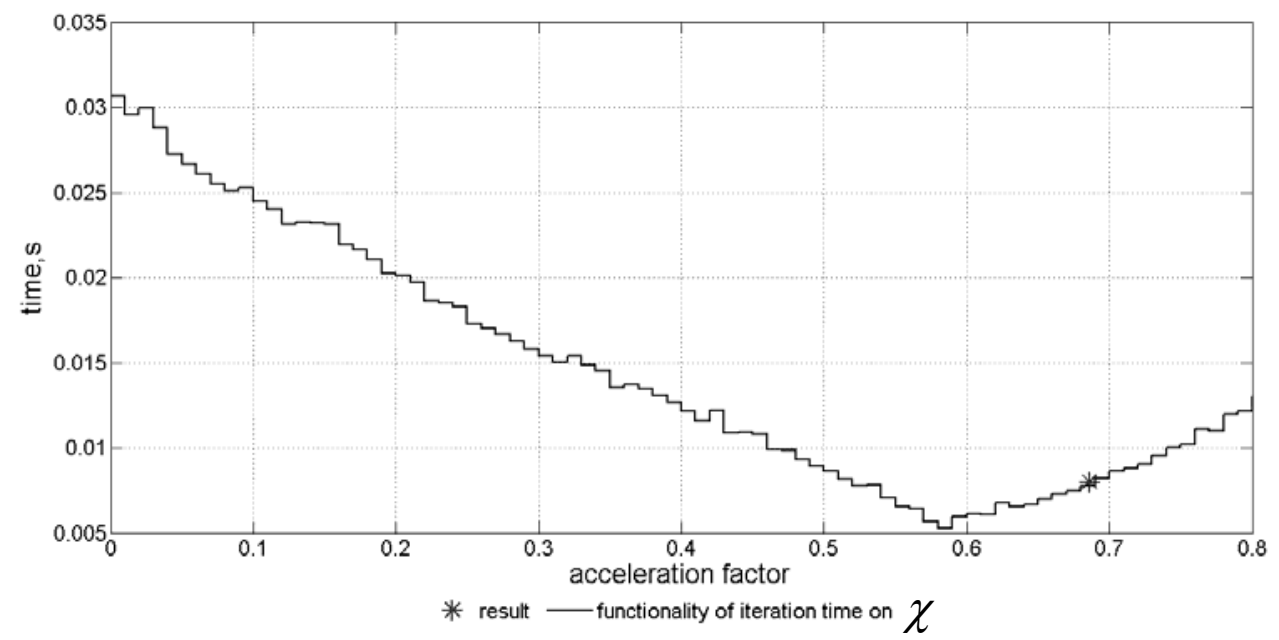

Fig. 9. Test results for the IEEE 14-bus test system. 
The results of testing the IEEE 30-bus system are: the admittance matrix condition number $K(Y)=421.27$, the calculated acceleration factor $\chi_{o p t}=0.831$; the iteration process time without acceleration $16.6 \cdot 10^{-2} \mathrm{~s}(\chi=0)$, with calculated acceleration $2.74 \cdot 10^{-2} \mathrm{~s}(\chi=0.831)$ (as above, the time is accounted for that is needed to define the condition number); the process time with optimal acceleration is $1.73 \cdot 10^{-2} \mathrm{~s}(\chi=0.74)$. The test results are displayed in Fig. 10 .

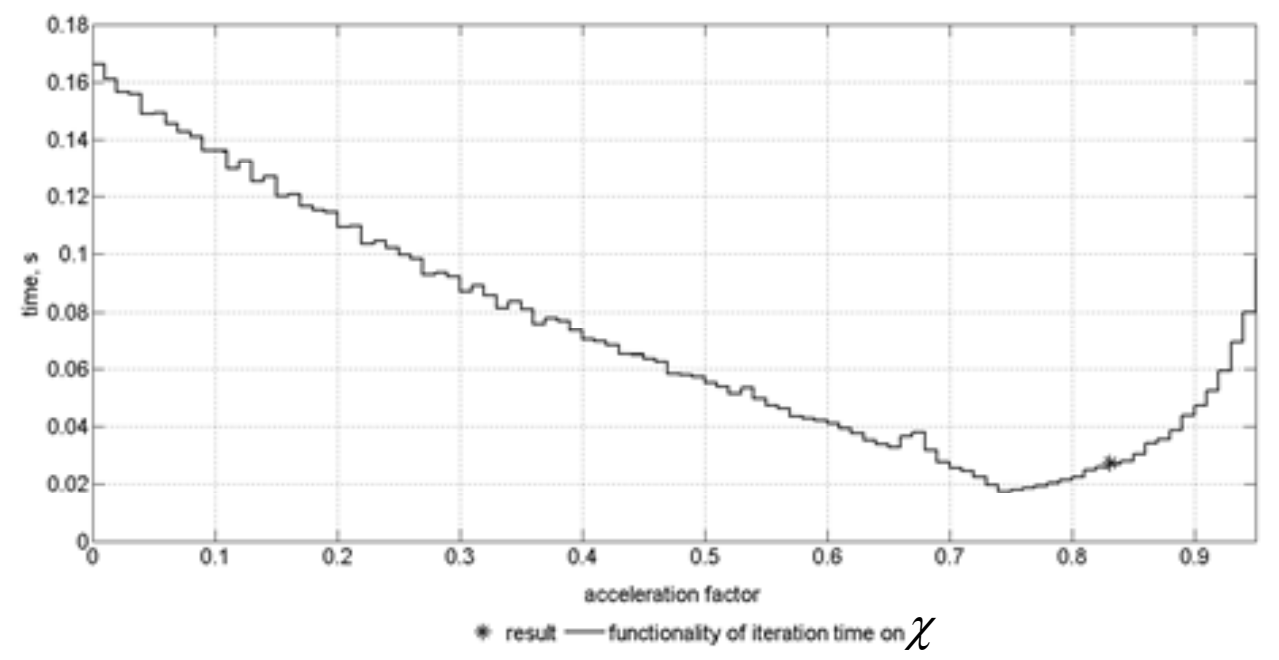

Fig. 10. Test results for the IEEE 30-bus test system

\section{CONCLUSIONS}

The optimal acceleration factor value has been determined using the derived empirical equations. The tests of 6-bus, IEEE-14 and 30-bus test systems show that the use of the determined acceleration factor allows reducing the calculation time 4-8 times. The results obtained are expected to be useful for future integration of Baltic electricity markets envisaged by the EU energy security and solidarity action plans. This research reflects one of the most topical problems that should be solved in the nearest future, with the results to be used for the tasks of modelling and development of power transmission networks.

\section{REFERENCES}

1. Commission of the European Communities. Second Strategic Energy Review "An EU energy security and solidarity action plan" COM/2008/781/Final. Brussels, Belgium, 13 November 2008.

2. Final Report of the High Level Group: Baltic Energy Market Interconnection Plan. Vilnius, Lithuania, 25 November 2009.

3. The Baltic Sea Region States reach agreement on the Baltic Energy Market Interconnection Plan. IP/09/945. Brussels, Belgium, 17 June 2009.

4. Krishans, Z. (1998). Modelling and Optimization Methods. Riga: RTU (in Latvian).

5. Krishans, Z., Mutule, A., Merkuryev, Y., Oleinikova, I. (2010). Dynamic Management of Sustainable Development: Methods for Large Technical Systems. Berlin: Springer.

6. Dale, V., Krishans, Z., Paegle, O. (1979). Dynamic Methods for Power Networks Development Analysis. Riga: Zinatne (in Russian). 
7. Christie, Richard D. Power Systems Test Case Archive, Dept. of Electrical Engineering, University of Washington, Seattle, WA, [Online]. Available: http://www.ee.washington.edu/research/pstca/.

\title{
ENERGOSISTĒMU ATTĪSTĪBAS OPTIMIZĀCIJA, IZMANTOJOT JAUDAS PLŪSMU APRĒKSINĀ PAĀTRINĀJUMA KOEFICIENTU
}

\author{
A. Obuševs, I. Oḷeiņikova, Z. Krišāns \\ Kopsavilku ms
}

Rakstā apskatītas ES iniciatīvas Baltijas valstu tālākai integrācijai ES energeêtikas nozarē un Baltijas enerǵētikas tirgus starpsavienojumu plānā (BETSP), lai nodrošinātu Baltijas valstu enerǵētisko neatkarību. BETSP ietver trīs virzienus starpsavienojumu izveidošanu (kas aptver dabas gāzes un elektroenerǵijas sistēmas savienojumu), vēja ǵenerāciju un $\left(\mathrm{CO}_{2}\right)$ uzkrāšanas shēmu.

Rakstā galvenā uzmanība vērsta uz elektriskā tīkla modelēšanas un attīstības jautājumiem visā Eiropā. Nākamo piecu gadu laikā ievērojami pieaugs elektrības integrācija Baltijā un būs iespējams palielināt tirgus likviditāti regiionā. Nozīmīgi starpsavienojumu projekti nākotnē ir divas pārrobežu saiknes ar Zviedriju un Somiju. Viens no projektiem ir Estlink II ar jaudu 650 MW (2014), finansējums ir aptuveni 100 miljoni EUR, un Lietuvas-Zviedrijas starpsavienojums ar jaudu 700 MW (2016), kam piešķirti aptuveni 175 miljoni eiro no ES fondiem. Šajā kontekstā ir ḷoti aktuāls jautājums ne tikai par integrāciju, bet arī par Baltijas, Skandināvijas un kontinentālās Eiropas pārvades tîkla sistēmu.

Tā rezultātā Latvijā tiks nodrošināta pārvades tīkla infrastruktūras attīstība Kurzemes reǵionā, kā arī būs iespējams pieslēgt lielu skaitu vēja geneneratoru un plānoto elektrostaciju Liepājā ar uzstādīto jaudu 400 MW. Turklāt „Kurzemes loks” palielinās Baltijas pārvades tīkla elektroenerğijas importu vai eksportu no LietuvasZviedrijas starpsavienojuma (līdzstrāvas kabelis).

Tāpēc ļoti aktuāls ir jautājums par pārvades tīkla modeḷa izveidi, lai aplūkotu staciju un apakšstaciju shēmas, drošības jautājumus, izvēlētos automatizācijas iekārtas. Lai veiktu sarežğītu sistēmu analīzi, ir nepieciešams ļoti liels aprēḳinu apjoms par visu elektrisko tīklu sistēmu kopumā. Uzdevums ir l̦oti sarežğìts, tāpēc, lai to atrisinātu, aprēķins tiek sadalīts šādās sastāvdaḷās: 1) modeḷu izstrāde un to pielāgošana, 2) apakšstacijas, releju aizsardzības un automātikas sistēmu izvēle un aprēķins, 3) tehniski ekonomiskā analīze.

Šajā rakstā apkopotais materiāls atspoguḷo metodikas pirmo daļu: aktīvās jaudas plūsmas aprēḳinu pārvades tīklam kopumā. Pētījuma rezultāti tiks izmantoti Latvijas dinamiskajā modelī (LDM), kas paredzēts enerǵētikas modelēšanas jautājumiem.

11.04.2011. 